\title{
Mineralogical and Technological Features of Tin Minerals at Pravourmiysky Deposit (Khabarovsk Region)
}

\author{
T. Chikisheva ${ }^{1,2,3(凶)}$, S. Prokopyev ${ }^{1,2,3}$, E. Kolesov ${ }^{4}$, V. Kilin ${ }^{4}$, \\ A. Karpova ${ }^{1,3}$, E. Prokopyev ${ }^{1,2}$, and V. Tukuser ${ }^{1,3}$ \\ ${ }^{1}$ LCC PC «Spirit», Irkutsk, Russia \\ chikishevatatyana@mail.ru \\ ${ }^{2}$ Institute of the Earth Crust SB RAS, Irkutsk, Russia \\ 3 Irkutsk State University, Irkutsk, Russia \\ ${ }^{4}$ PJSC «RUSOLOVO», Moscow, Russia
}

\begin{abstract}
The paper presents the data obtained in the process of mineralogical studies of technological samples of tin ore from the Pravourmiysky deposit. The authors studied in detail the mineralogical features of ores and tin-containing minerals and their significance for the enrichment technology. During of the study, the information on the main technological properties of the ore of the deposit was clarified and supplemented. As a result of the study of the mineral composition, the mineralogical features of the ore were identified, allowing to select the methods of ore enrichment and predict the quality of the concentrates and products obtained. The causes of loss of tin with tailings were established. The obtained data on the mineral composition, properties of ore minerals, and textural and structural features of the ores will be applied when modernizing their enrichment technology at the processing plant.
\end{abstract}

Keywords: Mineralogical research $\cdot$ Tin ores $\cdot$ Tin minerals

\section{Introduction}

In the $21^{\text {st }}$ century, tin is very in demand in the global economy due to its use in new industries, the introduction of innovative technologies and the environmental friendliness of metal. At the same time, the tin market is volatile, depending on sharp fluctuations in the price situation and annual changes between supply and demand [1].

Russian industry consumes about 6.5-7 thousand tons of tin per year. About $90 \%$ of the mined tin is imported. Tin deposits in Russia are among the richest in the world. Pravourmiyskoe tin deposit is one of the promising ore deposits of tin. In addition, together with tin, tungsten can be mined from ore deposits. To achieve a more complete extraction of valuable components from the ore, a detailed study of the mineral composition of ores, the textural and structural features of the ore, the physical properties of minerals and the degree of their contrast is necessary. Mineralogical analysis is the basis for the study of the material composition, structure and texture, choice of directions and methods of preparing raw materials for processing, enrichment technologies and 
metallurgy [2]. the paper is devoted to the study of the mineralogical and technological features of the Pravourmiysky deposit tin ores in the Far East.

\section{Methods and Approaches}

The object of the research was technological samples of tin ore from the Pravourmiisky deposit. The mineral composition of the ore and the quantitative assessment of the contents of each mineral were determined using the methods of optical microscopy and using x-ray methods. Mineralogical analysis of ore crushed to a particle size of less than $2 \mathrm{~mm}$ was carried out according to the methods of the Scientific Council on methods of mineralogical research. The sequence of operations to determine the mineral composition of the ore samples consisted in dividing the initial material of the samples into size classes, followed by gravitational fractionation and studying the distribution of minerals into fractions for each size class.

\section{Results and Discussion}

The main ore mineral of tin at the Pravourmiysky deposit is cassiterite. Stannin, mawsonite, stannoidite are present in small quantities. More than $98 \%$ of the tin in the ore is in cassiterite, $1-2 \%$ of the tin is in the sulphide minerals of tin.

Streaks, inclusions and clusters of grains of cassiterite, arsenopyrite and lellingite represent ore mineralization. The size of individual grains of ore minerals is up to $5.0 \mathrm{~mm}$, the apparent thickness of clusters is up to $60 \mathrm{~mm}$. Cassiterite is observed in the form of xenomorphic grains, their clusters; crystals of a prismatic, pyramidalprismatic appearance are less often observed (Fig. 1). The grains size of cassiterite varies from 0.01 to $2.0 \mathrm{~mm}$, with a predominance in the range of $0.1-0.5 \mathrm{~mm}$, the thickness of clusters of 3-5 mm, sometimes can reach up to $10.0 \mathrm{~mm}$.

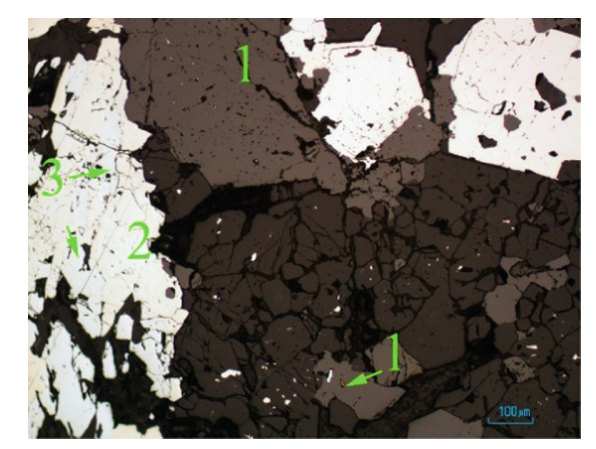

Fig. 1. Micrograph of cassiterite (1) in the intergrowth with arsenopyrite (2), lellingite (3).

According to the mineralogical analysis, crushed ore mainly consists of fragments of greisen, quartz, topaz, tourmaline, feldspar and mica. Ore minerals (arsenopyrite, 
lellingite, bornite and chalcopyrite) in crushed ore are in the form of fragments of crystals and grains of irregular shape. Sometimes they are found in intergrowths with each other and with rock-forming minerals.

Cassiterite is observed in the form of irregular shape grains, as well as in intergrowths with rock-forming minerals, less often with arsenopyrite or lellingite. The results of the study of the disclosure of cassiterite grains are shown in Table 1.

Table 1. Disclosure of cassiterite grains in crushed ore

\begin{tabular}{l|l|l|l}
\hline Size class, $\mathrm{mm}$ & $\begin{array}{l}\text { Cassiterite grains and cassiterite - } \\
\text { rich intergrowth, \% }\end{array}$ & $\begin{array}{l}\text { Cassiterite-containing } \\
\text { intergrowth, \% }\end{array}$ & Total \\
\hline$-2+1$ & 96,9 & 3,1 & 100,0 \\
\hline$-1+0,5$ & 98,9 & 1,1 & 100,0 \\
\hline$-0,5+0,315$ & 98,2 & 1,8 & 100,0 \\
\hline$-0,315+0,25$ & 99,8 & 0,2 & 100,0 \\
\hline$-0,25+0,125$ & 99,8 & 0,2 & 100,0 \\
\hline$-0,125+0,071$ & 99,9 & 0,1 & 100,0 \\
\hline$-0,071+0,040$ & 100,0 & 0,0 & 100,0 \\
\hline$-0,040+0,0$ & 100,0 & 0,0 & 100,0 \\
\hline
\end{tabular}

According to Table 1, in ore crushed to a particle size of less than $2 \mathrm{~mm}$, cassiterite grains are mainly in the form of free grains. The maximum number of intergrowths $(3.1 \%)$ is noted in the size class $-2+1 \mathrm{~mm}$. The complete disengagement of cassiterite grains from intergrowths is achieved in size less than $0.071 \mathrm{~mm}$.

Tin sulphide minerals (stannin, mawsonite, stannoidite) are associated with later copper mineralization. These minerals are in close intergrowth with chalcopyrite and bornite. Their size usually does not exceed $0.1 \mathrm{~mm}$.

\section{Conclusions}

Tin minerals, which are valuable components of the studied samples, have a significantly higher degree of contrast of gravitational properties, which can be used for their primary concentration Together with cassiterite and stannine, wolframite, arsenopyrite with lellingite and copper sulphides will be extracted into the primary gravity concentrate. To obtain tin concentrate that meets the requirements for raw materials, arsenopyrite and copper sulfides can be extracted from the rough concentrate using flotation methods.

During the flotation process, the sulfide minerals of tin (stannin, mawsonite, stannoidite) are extracted into sulfide products along with the minerals of copper and arsenic. To extract tin sulfides minerals, selective flotation with preliminary fine grinding of sulfide products will be required.

Differences in the magnetic susceptibility of minerals, with the use of magnetic separation, wolframite, biotite and tourmaline can be distinguished. 
Studying the contrast of the physical properties of ore minerals provided an idea of the mineral composition of the products of primary gravity enrichment, which will make it possible to develop an optimal scheme for finishing operations.

Acknowledgements. The Irkutsk State University, individual research grant № 091-18-231, supported this work.

\section{References}

1. Bashlykova TV (2005) Tekhnologicheskie aspekty racional'nogo nedropol'zovaniya: Rol' tekhnologicheskoj ocenki v razvitii i upravlenii mineral'no-syr'evoj bazoj strany [Technological aspects of rational subsoil use: The role of technological assessment in the development and management of the country's mineral resource base]. Moscow^ MiSIS (in Russian)

2. Danilov UG, Grigoryev VP (2017) Problemy i perspektivy razvitiya olovyannoj promyshlennosti Rossii. Gornaya promyshlennost' 5(135):83-87 (in Russian)

Open Access This chapter is licensed under the terms of the Creative Commons Attribution 4.0 International License (http://creativecommons.org/licenses/by/4.0/), which permits use, sharing, adaptation, distribution and reproduction in any medium or format, as long as you give appropriate credit to the original author(s) and the source, provide a link to the Creative Commons license and indicate if changes were made.

The images or other third party material in this chapter are included in the chapter's Creative Commons license, unless indicated otherwise in a credit line to the material. If material is not included in the chapter's Creative Commons license and your intended use is not permitted by statutory regulation or exceeds the permitted use, you will need to obtain permission directly from the copyright holder.

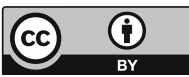

